\title{
The Pathos of Function: Leonardo's Technical Drawings
}

I.

A late pen and ink drawing by Leonardo da Vinci, now in Windsor Castle (W 12698 recto, ca. 1513), reverses ideas common in the Renaissance about the sometimes antagonistic relationship between nature and culture (fig. 1). In contrast to his almost contemporary "Deluge Series," the drawing does not show the worst case scenario of meteorology, destroying the creations of man, but a flood of tools and instruments that fall on the surface of the earth. We identify, among other objects, pincers, hammers, nails, angles, glasses, rulers, rakes, bottles, bagpipes, ladders, clocks, plates, discs, and what is more, among the clouds, a lion. In contrast to a line on the top of the sheet - "Here Adam and here Eve" - which probably belonged to another sketch on the same sheet, later cut off, ${ }^{1}$ the legend of the actual drawing leaves no doubt about its pessimistic meaning: "O miseria umana, di quante cose per danari ti fai servo. - O human misery, to how many things are you enslaved just for the money." Related to the lion in the clouds, the sketch becomes a prodigy (cf. Peter Apian, Practica for 1532, Landshut 1531; fig. 2), perhaps alluding to the proverbial technophilia of the Florentines - city of the Marzocco - or a crypto-signature of Leone-Leonardo himself. ${ }^{2}$ But it is more reasonable, I believe, to interpret the lion as a reference to Pope Leo X, elected in 1513, a person who raised many hopes in Leonardo, which turned, however, into disappointment and complaints. As is well known, Leonardo was denounced before the Pope because of his ana-

1 Cf. Kenneth Clark. The Drawings of Leonardo da Vinci in the Collection of H. M. The Queen at Windsor Castle. 3 vols. London: Phaidon, 1968. Vol. 1, sub num.

2 Cf. Pierce Dominic Britton. "Lionizing Leonardo. A Physiognomic Conceit in Vasari's 'Vite." Source 22.4 (2003): 10-15; Cecilio Paniagua. "Notes on a Drawing by Leonardo da Vinci.” International Review of Psychoanalysis 13 (1986): 445-52. 


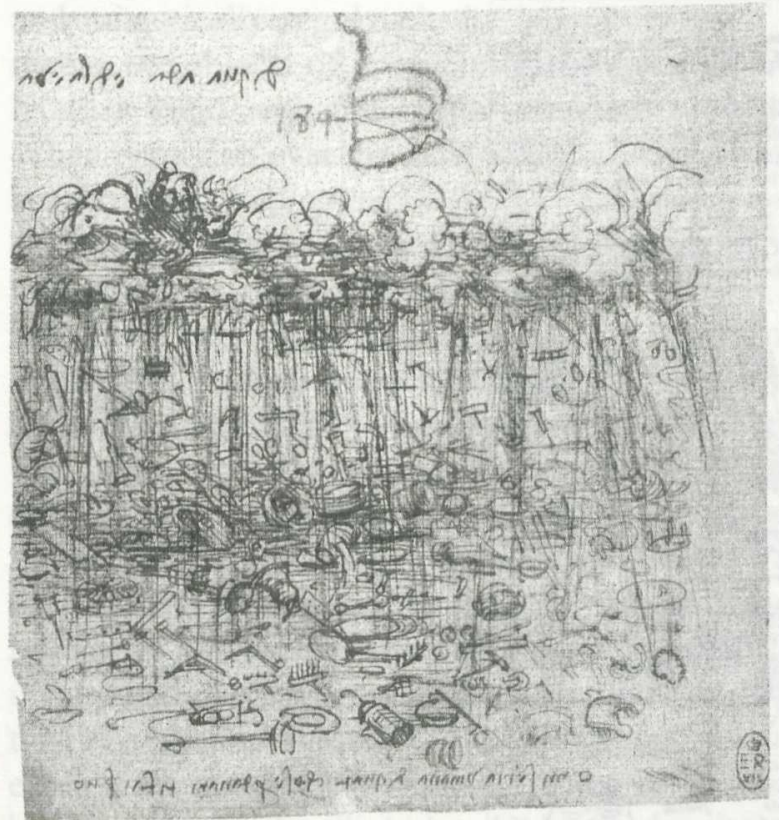

Fig. 1: Leonardo da Vinci. Deluge of tools. Pen and black chalk, ca. 1510-15. Windsor, Royal Library, No. 12698 recto.

tomical research. ${ }^{3}$ The drawing could reasonably be interpreted as an allegory of the utilitarian limitations of technology "under the sign of Leo." However, Leonardo's bitter lemma emphasizes that greed is the true reason for the deluge of tools that cover the whole surface of the earth. Greed is the driving force behind the emotional involvement in discovery and measurement, ironically documented by countless drawings and manuscript pages of our master technologist himself. ${ }^{4}$

3 On Leonardo's complaint, cf. Codex Atlanticus, fol. 500. Cf. Domenico Laurenza. "Leonardo nella Roma di Leone X (c. 1513-16)." XLIII Lettura Vinciana. Florence: Giunti, 2004. Cf. also Leonardo's cryptic contemporary notice: "li medjci mi crearono e desstrussono" (Codex Atlanticus, fol. 429r; on this passage, cf. Carlo Pedretti. The Literary Works of Leonardo da Vinci. Commentary. 2 vols. London: Phaidon, 1977. Vol. 2, 313f., with doubts about a reference to the Florentine family). On the identification of lion and Leo X and on the relevant Medici iconology, cf. Suzanne B. Butters. The Triumph of Vulcan. Sculptor's Tools, Porphyry, and the Prince in Ducal Florence. 2 vols. Florence: Olschki, 1996. Vol. 1, 58f. On Leonardo's lion automat for the Florentines in Lyon, on the occasion of the entrance of François I (12 July 1515), cf. Pedretti. Literary Works. 303.

4 On a similar representation by Maarten van Heemskerck, showing the globe covered by instruments and tools (1572), cf. Horst Bredekamp. "Der Mensch als 'zweiter Gott.' Motive der Wiederkehr eines kunsttheoretischen Topos im Zeitalter der 


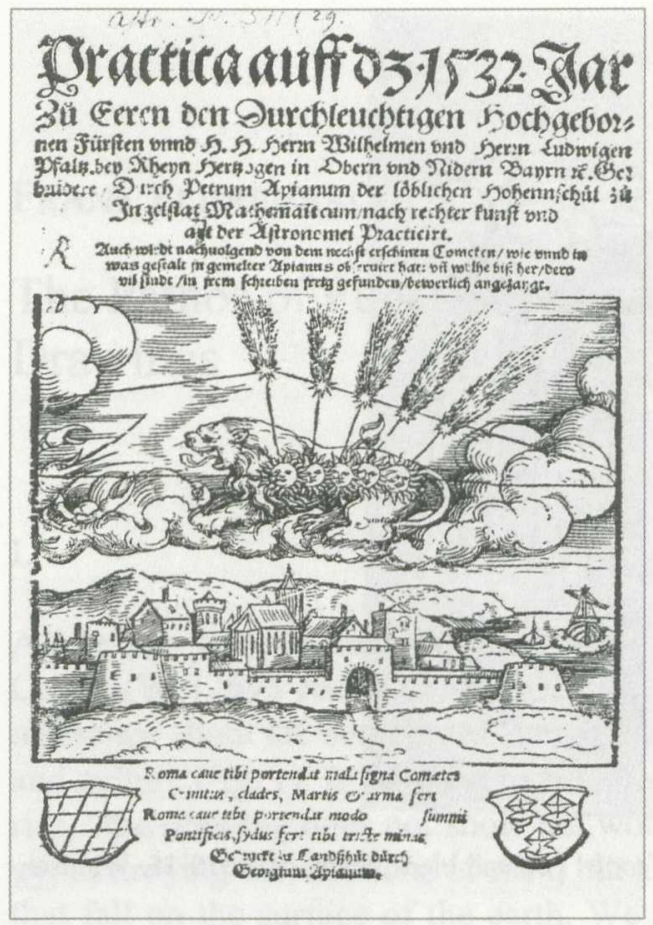

Fig. 2: Peter Apian. Practica for 1532 (Landshut, 1531).

Evidently, the tools that measure, order, straighten, regulate, and adjust are themselves in need of some kind of order. The history of images of technical instruments shows that these trophies of science are marked by a secret unruliness and abundance. Under the command of the new paradigm - mechanics, allegorically boasting as a lansquenet in the period of the Thirty Years' $\mathrm{War}^{5}$ - this should come to an end. The wellequipped laboratory is not only the place where the world is logically

Bildsimulation." Interface 1. Elektronische Medien und künstlerische Kreativität. Ed. Klaus Peter Dencker. Hamburg: Verlag Hans-Bredow-Institut für Rundfunk und Fernsehen, 1992. 134-47. On the engraving, cf. Ilja M. Veldman and Ger Luijten. Maarten van Heemskerck. (= The New Hollstein. Dutch \& Flemish Etchings, Engravings, and Woodcuts 1450-1700). 2 vols. Amsterdam: Sound \& Vision Interactive, 1994. Vol. 2, No. 501/1.

5 Cf. the engraving 'Mechanica and her daughters and sons' in Joseph Furttenbach's Mechanische Reißladen ... Augsburg, 1644. Cf. Jutta Bacher. "Das Theatrum machinarum. Eine Schaubühne zwischen Nutzen und Vergnügen." Erkenntnis Erfindung - Konstruktion. Studien zur Bildgeschichte von Naturwissenschaften und Technik vom 16. bis zum 19. Jahrhundert. Ed. Hans Holländer. Berlin: Mann, 2000. 255-97, and her “'Ingenium vires superat.' Die Emanzipation der Mechanik und ihr Verhältnis zu Ars, Scientia und Philosophia.” Ibid. 519-55. 
and numerically regulated; the laboratory itself must tame the instruments, the objects of intervention. The classification of the world goes hand in hand with the spatial disposition of classifying instruments. When dominion over the tools weakens, an ancient chaos reemerges - the epoch post technologiam.

Leonardo's drawing, a writing on the wall about the "second nature" realized by human technology, ${ }^{6}$ contains, perhaps, the palette of a painter but not - that would have been hard to represent on the tiny sketch one of the smallest but nevertheless most sophisticated tools of human dominion over nature - the draftsman's instrument. It is due to the pen that Leonardo's drawing exists, a rather significant difference to the abundant variety of the not at all heavenly instruments in the representation. It is exactly this peculiarity that identifies the pen with the origin of all tools. The scientific success story of early modern times would have been impossible without the minute but decisive transfers between mental and material concepts realized by the drawing pen. To be sure, this was already evident to the pioneers of this tool. Leonardo is very explicit about this. ${ }^{7}$ Drawing is nothing but moving a point; not a craft but the gesture of a "light hand," hardly leaving the trace of bodily activity behind - la pittura è mentale. ${ }^{8}$ Nevertheless, human culture depends on an almost non-dimensional feather point. "The beginning of painting is the point, followed by the line, the third is the surface." 9 Precisely at this point, the editors' proposal to insert Leonardo into a book on the culture of instruments in the seventeenth century makes sense.

For Leonardo, without pittura all the artes would be impossible, since their codifications require visual signs. Painting - and that means, in this place, drawing, since color is not mentioned at all - not only provides letters for language, numbers for arithmetic, and figures for geometry; it also teaches perspectivists, astronomers, machinists, and engineers (questa insegna alli prospettivi et astrolaghi et alli machinatori et ingegneri)..$^{10}$ Drawing, therefore, is not only a medium conveying knowledge; it also appears as the original invention par excellence,

6 "Gravity, force, together with material movement and percussion are the four accidental powers by which the human species in its adorable and various actions appears like a second nature. Because all the visual works of mortals have their being and their death because of these powers." (Leonardo, Codex Arundel, fol. 151v. ca.1495-97).

7 Cf. Leonardo da Vinci. Manuscript E, fol. $34 \mathrm{v}$.

8 Leonardo da Vinci. Libro di Pittura. Ed. Carlo Pedretti. Florence: Giunti, 1995, §31c.

9 Ibid. $\S 3$.

10 Ibid. $\S 23$, cf. ibid. $\S 31 \mathrm{~b}$. - A good collection of drawing tools is provided by Maja Hambly. Drawing Instruments. 1580-1980. London: Wilson, 1988. 
giving birth to all other human inventions. Consequently, it would be obsolete to insert painting into the system of the artes liberales. Pittura claims a special rank, comparable, in a different context, only to theology.

Obviously, the theoretical claim that visual signs not only communicate, but generate knowledge, points to important epistemological decisions, harking back to the late medieval career of the Aristotelian phantasma. Per imaginem ad ideam: This reveals a clear succession, especially if the inner images are related incontrovertibly to their origin, the senses. ${ }^{11}$ However, the praise of the minute, of speed, of the almost non-dimensional qualities of point and line, pen and drawing is related to older, Platonic paradigms. For instance, in Alberti's and Leonardo's apologia for the eye and the point, what is imprinted by the pen is itself a nusquam, leaving a trace when moved - the line. ${ }^{12}$ The material medium of the drawing evaporates, and becomes a transitional being between mind and matter, analogous to the spiritus. Later on, this idea could be transformed into an argument against the senses and in favor of art as a domain of the mind, as Georges Didi-Huberman has demonstrated. Vasari states:

Drawing, ... proceeding from the intellect [procedendo dall'intelletto], derives from many things a universal judgment [cava di molte cose un giudizio universale]: as it were a form or idea of all the things in nature [simile a una forma overo idea di tutte le cose della natura], which is exceedingly regular in its proportions. Thus it is that drawing, not only in the bodies of humans and animals, but also in plants, buildings, sculptures, and paintings, recognizes the proportion of the whole to its parts and of the parts to one another and to the whole [conosce la proporzione che ha il tutto con le parti, e che hanno le parti infra loro e col tutto insieme]. ${ }^{13}$

This is the foundation of "composition," deduced from the living body, since the mutual, proportional usefulness of parts and the whole is, according to Aristotle, a distinguishing formal property of the organism. ${ }^{14}$

11 Cf. Frank Fehrenbach. Licht und Wasser. Zur Dynamik naturphilosophischer Leitbilder im Werk Leonardo da Vincis. Tübingen: Wasmuth, 1997. 17ff.

12 Cf. Leon Battista Alberti. De pictura 1,2: "Puncta quidem si continenter in ordine iungantur lineam extendent. Erit itaque apud nos linea signum cuius longitudo sane in partes dividi possit. Sed erit usque adeo latitudine tenuissima ut nusquam findi queat."

13 Giorgio Vasari. Le vite de più eccellenti pittori, scultori et architettori . . . 3 vols. Florence: Gunti, 1568. Vol. 1, 168f. Quoted in Georges Didi-Huberman. Confronting Images. Questioning the Ends of a certain History of Art. Pennsylvania: Pennsylvania State University Press, 2005. 78.

14 Cf. Aristotle. De partibus animalium/Parts of animals. Greek/Eng., transl. A.L. Peck. Cambridge: Cambridge University Press, 1983. 645bff. On the complex history of early modern 'composition,' cf. Hans Körner. Auf der Suche nach der 'wah- 
Some years later, in Federico Zuccari's writings, the fusion of idea and disegno will be complete, depriving disegno even of the thin line of the fragile pen and of the emanations at its tip. "Almost another divinity, another productive nature, in which live the things produced by art ... Internal and external light of the intellect ... Nourishment and life of all science and practice." ${ }^{15}$ But the anti-naturalistic temptations lurking behind this statement are bypassed in the specific cultural situation of the later sixteenth century. Art together with visuality becomes, instead, a "meta-techne"16 of a scientific practice that encourages experiments, proceeding primarily along the paradigms of mapping and collecting, emphasizing at the same time the non-numerical, 'morphological' areas of research of the sixteenth century. These are, among others, mainly biology, medicine, alchemy, hydrology, and geology, which feature prominently in Bacon's Atlantis and remain, together with perspective and optics, the preferred disciplines of many non-Cartesian scientists in the seventeenth and eighteenth centuries. Describing this process of take-over by drawing in 1658, Gassendi coins the accurate phrase, Baconian in spirit (Syntagma philosophicum): "We investigate the objects of nature the same way in which we investigate the things we have created ourselves." ${ }^{17}$ But the unity of interpretation and intervention, of knowing and producing can be related, as Wolfgang Krohn recently demonstrated, to Alberti's efforts to establish the scientific status of architecture. ${ }^{18}$ This argument brings drawing as a medium of experiment into play. But the drawing's interventionist, constructivist character remains connected to

ren Einheit.' Ganzheitsvorstellungen in der französischen Malerei und Kunstliteratur vom mittleren 17. bis zum mittleren 19. Jahrhundert. Munich: Fink, 1988; Thomas Puttfarken. The Discovery of Pictorial Composition. Theories of Visual Order in Painting 1400-1800. New Haven and London: Yale University Press, 2000; Frank Fehrenbach. "Komposition." Metzler Lexikon Kunstwissenschaft. Ideen, Methoden, Begriffe. Ed. Ulrich Pfisterer. Stuttgart and Weimar: Metzler, 2003. 178-83.

15 This text is reprinted in Romano Alberti. Origini e progresso dell'Accademia del Disegno de'Pittori, scultori et architetti di Roma. Padua, 1604. Quoted in DidiHuberman. Confronting Images. 84.

16 Cf. Robert Williams. Art, Theory, and Culture in Sixteenth-Century Italy. From Techne to Metatechne. Cambridge: Cambridge University Press, 1997.

17 Pierre Gassendi. Syntagma philosophicum. Lugduni, 1658. Quoted in Hans Holländer. "Spielformen der Mathesis universalis." Erkenntnis - Erfindung - Konstruktion. Studien zur Bildgeschichte von Naturwissenschaften und Technik vom 16. bis zum 19. Jahrhundert. Ed. idem. Berlin: Mann, 2000. 325-345 (328).

18 Wolfgang Krohn. "Technik, Kunst und Wissenschaft. Die Idee einer konstruktiven Naturwissenschaft des Schönen bei Leon Battista Alberti." Leonardo da Vinci. Natur im Übergang. Beiträge zu Kunst, Wissenschaft und Technik. Ed. Frank Fehrenbach. Munich: Fink, 2002. 37-56. 
visual evidence and thus to the sensus communis of its addressees and, in the case of technical concepts, to their successful realization.

Against this background, favorable to images, experiments, and construction, the social revaluation of the draftsman became almost inevitable. The thirteen-year-old Dürer represented himself in the famous silver point drawing in the Albertina (1484) as a second, teaching Christ Child, with the pointing right hand of the draftsman, fixing his concentrated gaze on an unknown object. ${ }^{19}$ Even less than the colors of the painter, who mocks, with Leonardo, the dirt-covered, sweating sculptor, drawing left no ugly traces of material action. ${ }^{20}$ With this, an older controversy was repeated within the guild of the painters themselves the strife between dirty and 'philosophical' activity. ${ }^{21}$ Even color-orientated princes of painting were better off not to look like fools to the party of (Florentine) intellectuals - and ostentatiously presented the drawing pen rather than the brush, like, for instance, Titian in a lost self-portrait, documented in a woodcut by Giovanni Britto (1550). ${ }^{22}$ Prior to this, Baldassare Castiglione, in his authoritative concept of the courtly uomo universale, praised drawing as an indispensable activity of nobility. ${ }^{23}$

The references by Pliny the Elder and Alberti to painting knights and even emperors of antiquity had their effect. ${ }^{24}$ This development is

19 Joseph Leo Koerner mentions the parallels with the pointing Jesus of the 'Holy Family' in Berlin, ca. 1492-93 (Kupferstichkabinett, SMPK). Cf. Joseph Leo Koerner. The Moment of Self-Portraiture in German Renaissance Art. Chicago: University of Chicago Press, 1993. 14 and $42 \mathrm{ff}$.

20 Leonardo. Libri di Pittura. $\S 36$.

21 On the tradition of the criterion, cf. Claire J. Farago. Leonardo da Vinci's 'Paragone.' A Critical Interpretation with a New Edition of the Text of the 'Codex Urbinas.' Leiden: Brill, 1992. 139ff.; also George Ovitt. The Restoration of Perfection. Labor and Technology in Medieval Culture. New Brunswick and London: Rutgers University Press, 1987. Particularly instructive is David Summers. The Judgment of Sense. Renaissance Naturalism and the Rise of Aesthetics. $2^{\text {nd }}$ ed. Cambridge: Cambridge University Press, 1990. 259ff.

22 Joanna Woods-Marsden. Renaissance Self-Portraiture. The Visual Construction of Identity and the Social Status of the Artist. New Haven and London: Yale University Press, 1998. 228f.

23 'Un'altra cosa, la quale io ... penso che dal nostro cortegiano per alcun modo non debba esser lasciata addietro: e questo è il saper disegnare ed aver cognizion dell'arte propria del dipingere." Baldassare Castiglione. Il libro del cortegiano. Ed. Walter Barberis. Turin: Einaudi, 1998. XLIX.

24 Gaius Pliny the Elder. Natural History. Trans. H. Rackham. Cambridge: Harvard University Press, 1979; idem. Historia naturalis/Naturkunde. Latin/German. Ed. and trans. Roderich König. Munich and Darmstadt: Artemis \& Winkler, $1973 \mathrm{ff}$. Vol. XXXV. 20-22; Leon Battista Alberti. On Painting. New York: Penguin, 1991. 65-66. 


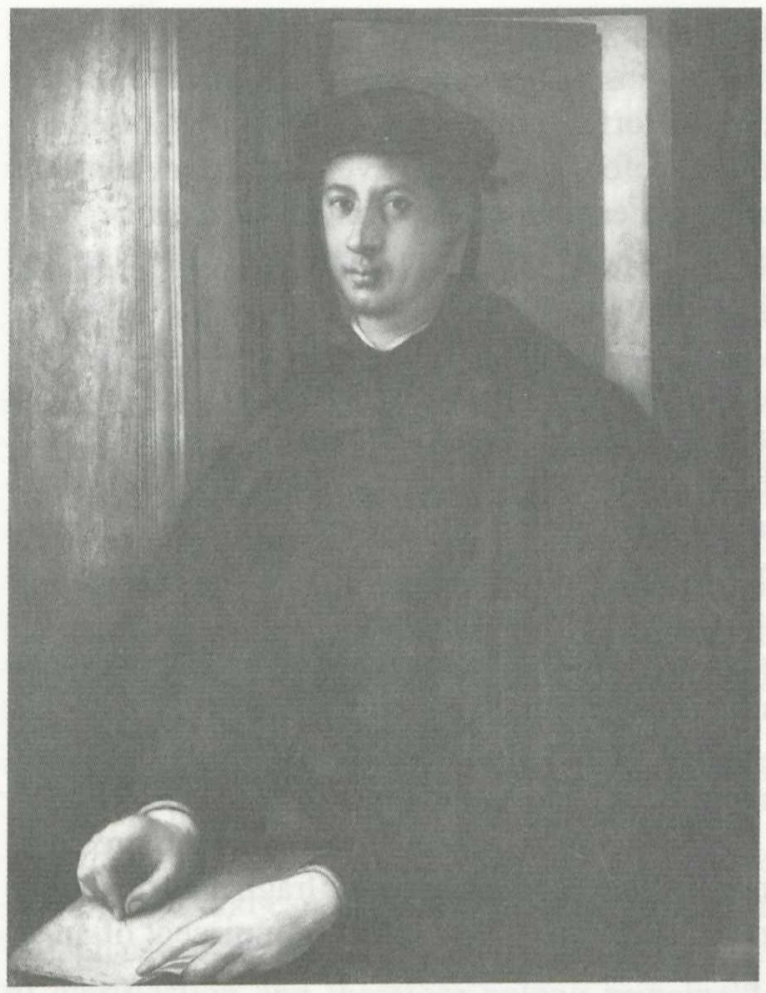

Fig. 3: Jacopo Pontormo. Alessandro de Medici. Oil on wood panel, 1534. Philadelphia Museum of Art, Johnson Collection.

convincingly mirrored in Jacopo Pontormo's portrait of the first Florentine Medici Duke, Alessandro, who was assassinated shortly after the completion of the painting (fig. 3). Politically a figure who did not avoid dirty labor, and far from fastidious in matters of love, he appears, on the panel, as a drawing aesthete. On the other side of the picture surface, the painter Pontormo, however, is virtually transformed into Alessandro's lover, Taddea Malaspina, drawn in this everlasting moment, with a subtle metal point, by the princely bastard - no eternal adoration, but an eternal imitation in the service of the eternal preservation of beautiful bodily features. ${ }^{25}$ The chiasmus of the gaze transforms the lady who was intended to receive the painting into the portrait of a portrait. Evidently, the mourning of the galantuomo is not only caused by the death of an important protector and distant relative, Pope Clement VII de' Medici (1534), but also by the implicit absence of the beloved. The im-

25 Cf. Philippe Costamagna. Pontormo. Milan: Electa, 1994. Cat. no. 72. 
age redeems the prince despite the distance from his lover, like the daughter of a potter at the origins of drawing and/or sculpture, ${ }^{26}$ in grey contour lines on paper, but colorful in his heart - just as he himself appears, absent, but in colors, before his lover. Even before meeting the sovereign as wood-turner, we encounter the princely draftsman, who fixes his world on paper and who is trained in the tool of access to and subjection of the world through the geometrical magic of perspective. ${ }^{27}$ Complaints from the subordinates were not missing, since instrumental techniques are not only an analogy of princely dominion, they also set free the delightful passion associated with dilettantism. In situations in which the existence of the community is at risk, the prince should renounce "riding his horse on the turf, carving, turning, painting, or practising alchemy and other things entirely inappropriate to his rank," as the physician and ducal counselor Caspar Dornau admonished at the beginning of the Thirty Years' War. ${ }^{28}$ The sequence of his list interprets painting as a close relative to a speculative and magical art. We should not underestimate the pathos of this imitative recreation of the world through painting/drawing. In Enea Vico's representation of Baccio Bandinelli's Accademia (ca. 1550), the more or less drowsy students are busy, at night and by the light of fire and candles, drawing fragments of antique sculpture as well as parts of skeletons - a situation reminiscent of an al-

26 Cf. Pliny the Elder. Natural History. Vol. XXXV, 15 and 151. - Significantly, Leonardo conceives the first painting to have been a result of the shadow cast by the sun. Cf. Leonardo da Vinci. Manuscript A, fol. 97v.

27 Cf. for instance the letter of Jacopo de' Barbari to Frederick the Wise (1500/01): "And without knowledge of the seven Liberal Arts, no convincing painting can be produced by the painters; they have to master these Arts, first geometry, then arithmetic, both indispensable conditions for the measurements of proportion ... However, to represent these sciences in a painting, philosophy is again required - namely the remarks of Aristotle on the soul, where he discusses how images (species) reach the eye and how the objects are to be arranged on the empty surface of the painting, according to the knowledge of light rays ... There is no lack of talents, but of leisure and nobility! Because in the age of Alexander the Great, only noble and wealthy men were allowed to practice the art of painting." Cf. Ulrich Pfisterer, ed. Die Kunstliteratur der italienischen Renaissance. Eine Geschichte in Quellen. Stuttgart: Reclam, 2002. 268f. On the transformations of perspective in the sixteenth century, cf. the survey of Martin Kemp. The Science of Art. Optical Themes in Western Art from Brunelleschi to Seurat. New Haven and London: Yale University Press, 1990. 92. On the history of dilettantism, Wolfgang Kemp. … einen wahrhaft bildenden Zeichenunterricht überall einzuführen.' Zeichnen und Zeichenunterricht der Laien 1500-1870. Ein Handbuch. Frankfurt a.M.: Syndikat, 1979. Cf. also Klaus Maurice. Der drechselnde Souverän. Materialien zu einer fürstlichen Maschinenkunst. Zurich: Ineichen, 1985. 
chemical laboratory in the service of the revivification of fragmented, fleshless bodies. ${ }^{29}$

II.

The sheer quantity of Leonardo's surviving technical drawings is terrifying - about six thousand single sheets and manuscript pages, the largest legacy in the history of Renaissance technology. Evidently, many sketches were preserved because they benefited from the aura of the artist's ingenium - significantly, Vasari compares them to relics. ${ }^{30}$ What would have happened to Leonardo's technical drawings if his audience admired him not as the painter of the Milanese Last Supper and the unfinished Battle of Anghiari, but rather as a mechanical genius? The lion's share of these drawings consists of four subject matters: hydraulics, military technology, flying machines, and the countless sheets dedicated to fundamental problems of theoretical mechanics. The sheer number of drawings demonstrates that Leonardo was unwilling ever to put the pen down; he must have drawn continuously and - significantly - looked repeatedly at his own, older drawings. The range of graphic documents is enormous and can be inscribed ideally into a triangle, bounded by record, phantasmagoric sketch, and diagram. The drawings are in the service of clarification and therefore belong principally to a rhetorical ambience that harnesses the enargeia of the visual. In Leonardo's work, drawing for the first time claims priority in the history of technology and of the genre of illustrated treatises. ${ }^{31}$

In Leonardo's career, the technological ingenium is also set free in social terms. His position is not strictly related to specific commissions and assignments. As a mobile counselor and inventor he moves with astonishing freedom between the different territories - Milan, Florence, Rome, at the end in Amboise and, almost, on the Bosphorus. His salary

29 On the engraving and on Bandinelli's academy, cf. Leonard Barkan. Unearthing the Past. Archeology and Aesthetics in the Making of Renaissance Culture. New Haven and London: Yale University Press, 1999. 289ff. Barkan does not notice the representation's dialectics of fragment and integrity, dead and alive, dark and bright.

30 Cf. Giorgio Vasari. Le vite ... 6 vols. Ed. Rosanna Bettarini and Paola Barocchi. Florence: Sansoni, 1966-1987. Vol. 4, 28.

31 For a contemporary parallel, Francesco di Giorgio Martini, cf. Paolo Galluzzi, ed. Prima di Leonardo. Cultura delle macchine a Siena nel Rinascimento. Milan: Electa, 1991 (with various examples of technical illustrations without accompanying text, for instance in the circle of Mariano di Iacopo, called Il Taccola). Cf. also Herbert Maschat. Leonardo da Vinci und die Technik der Renaissance. Munich: Profil, 1989; Domenico Laurenza. Le macchine di Leonardo. Florence: Giunti, 2005. 
as a mechanical genius is often independent of specific commissions. ${ }^{32}$ The unique freedom of Leonardo, however, required the support of elevated rhetoric. Different sources describe Leonardo's extraordinary eloquence, probably comparable to his graphic skills. ${ }^{33}$ The famous letter of application (ca. 1480) ) $^{34}$ to the then most powerful Duke in Italy, Lodovico Sforza, documented by a transcript in Leonardo's manuscripts, is a testament to the licentia of the thirty-year-old inventor. What he generously promises closely follows, both in content and in style, a medieval prophet of technological utopia, the Franciscan Roger Bacon, whom Leonardo will repeatedly refer to later on. Among the secreti miei, dangled as bait by Leonardo, pontoon bridges appear beside war ships, armored cars, mine technology, and diving devices - exactly those technologies of movement on and under earth and water imagined by Roger Bacon two hundred years before, which were intended to renew, as Horst Bredekamp has shown, the technological miracles of antiquity. ${ }^{35}$ Projects like the sickle car belong to this classicizing context (fig. 4). In this case however, Leonardo warns that this is a terribly powerful device, capable of bringing death and mutilation indifferently to friend and foe.

Leonardo's reputation as a technician, the willingness even of skeptical governments like the Venetian or the Florentine Republics to commission enormous (ultimately failed) public works, Leonardo's skill at turning pragmatic situations into poetic contexts, must be linked to his unique skills as a draftsman. I would like to highlight the characteristics of his drawings with the following keywords - perspective, geometry, and especially, movement.

A drawing in Windsor of ca. 1503/04 (fig. 5), produced in the context of Cesare Borgia's threats to attack the Florentine Republic, reflects these three criteria in nuce. Leonardo depicts a sophisticated defensive device that can attack an adversary who has already surmounted the outer ring of a fortress from behind. Leonardo demonstrates the bombardment by hidden underground ordnances as an actual event, drawing the semicircular trajectories of the projectiles in perfect beauty, almost like the abstract play of fountains. The graphic display of the foreshortened, elliptical

32 Cf. Paolo Galluzzi. Gli ingegneri del Rinascimento da Brunelleschi a Leonardo da Vinci. Florence: Giunti, 2001. 47ff.

33 "E con le parole volgeva al sì e al no ogni indurata intenzione." Vasari. Le vite. Ed. Bettarini and Barocchi. Vol. 4, 37.

34 Leonardo da Vinci. Codex Atlanticus, fol. 1082.

35 Cf. Domenico Laurenza. "Leonardo. Le macchine volanti." Le macchine del Rinascimento. Ed. Giovanni Morello. Rome: Retablo, 2000. 145-87; Horst Bredekamp. Antikensehnsucht und Maschinenglauben. Die Geschichte der Kunstkammer und die Zukunft der Kunstgeschichte. Berlin: Wagenbach, 1993. 


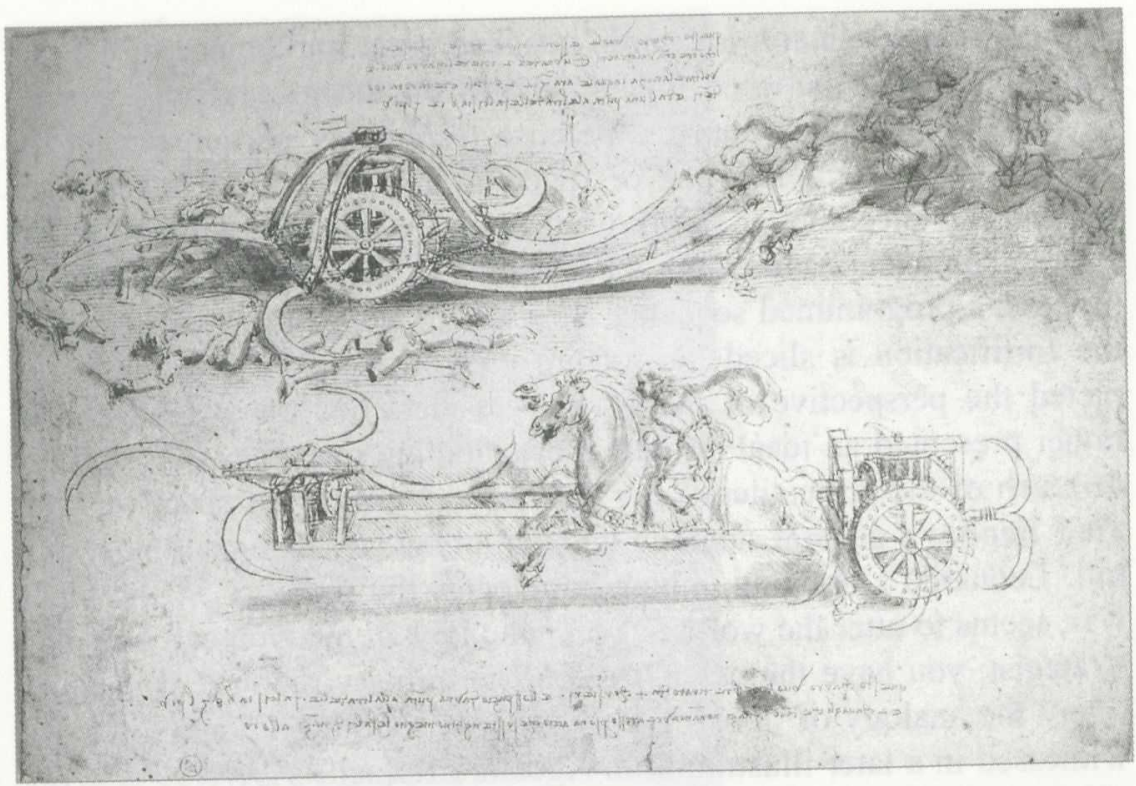

Fig. 4: Leonardo da Vinci. Sickle Car. Pen and ink, ca. 1490. Turin, Biblioteca Reale, No. 15583.

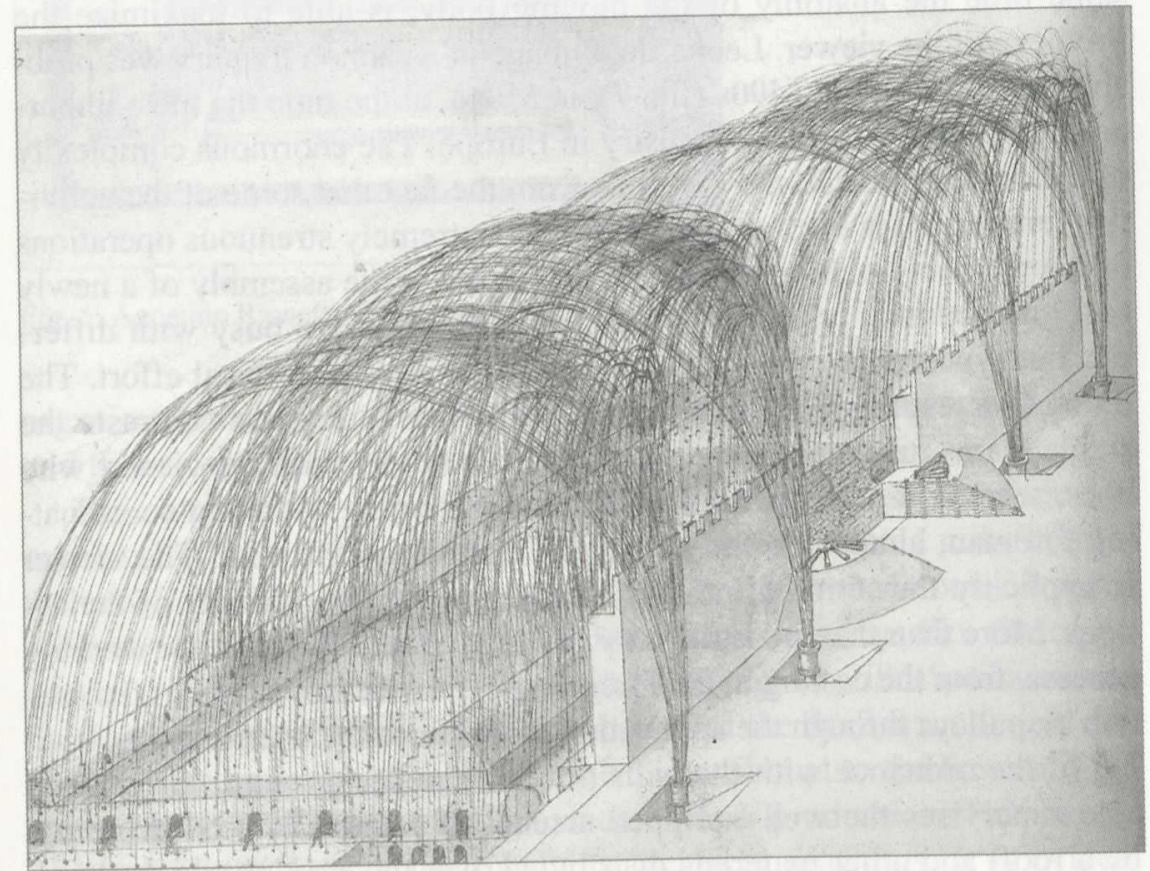

Fig. 5: Leonardo da Vinci. Military Project. Pen and ink, ca. 1503/04. Windsor, Royal Library, No. 12275. 
curves is extraordinary. Leonardo attached great importance to the fact that the distance between the projectiles on the ground was exactly identical. This signals that the defense technology participates in the geometrical perfection of the perspectival grid. The event takes place without the anecdotal addition of attacking or dead soldiers, on a perfectly plain, clean, and evenly lit terrain. The viewer observes an ideal process, a programmed sequence. In order to achieve greater visibility, the fortification is sliced by a sharp cut. Furthermore, Leonardo depicted the perspective of neither the invaders nor the defenders, but rather presented an ideal oblique view, floating over the walls and out of reach of the projectiles. Later called the "military perspective," this view implies a general standing upon an imaginary command post on a hill. Leonardo's drawing, which anticipates the esthetics of the video war, seems to utter the words: "You, who look at me, you can only be a strategist; you have the perspectiva." The military rhetoric of perspective - the analogy of 'looking through' and shooting through - can be witnessed in a later illustration in Agostino Ramelli's Diverse et artificiose machine (1588) (fig. 6).

Only a draftsman like Leonardo, who masters perspective and at the same time the anatomy of the moving body, is able to maximize the privilege of the viewer. Leonardo's image of a cannon foundry was probably produced in the 1490s (fig. 7), in Milan, at the time the most important center of the military industry in Europe. The enormous complexity of the drawing should not divert us from the fact that some of the activities remain rather unclear, especially the extremely strenuous operations of the workers on the right. The main subject is the assembly of a newly cast giant cannon on a cart. Many naked workers are busy with different, but synchronized actions that require the utmost physical effort. The drawing is especially persuasive in two respects. First, it contrasts the single teams, unable to overlook the whole scene, with the viewer who does; second, it presents the workers as functioning without a coordinating foreman, almost like an automated operational process. The viewer is implicitly transformed into the overseer or the programmer of the actions. More than that, he is the only one able to survey the entire working process, from the casting in the foreground with the movement of the cannon on pulleys through the application of hoists, to the later, implicit loading of the ordnance with the balls piled in the background. The viewer also supervises the well-equipped arsenal of cannon barrels (protected by a roof) and other materials distributed over the area. While the hardware - weapons, buildings, tools - is clearly outlined and well defined by perspective, the naked workers appear to be ephemeral collectives, an 


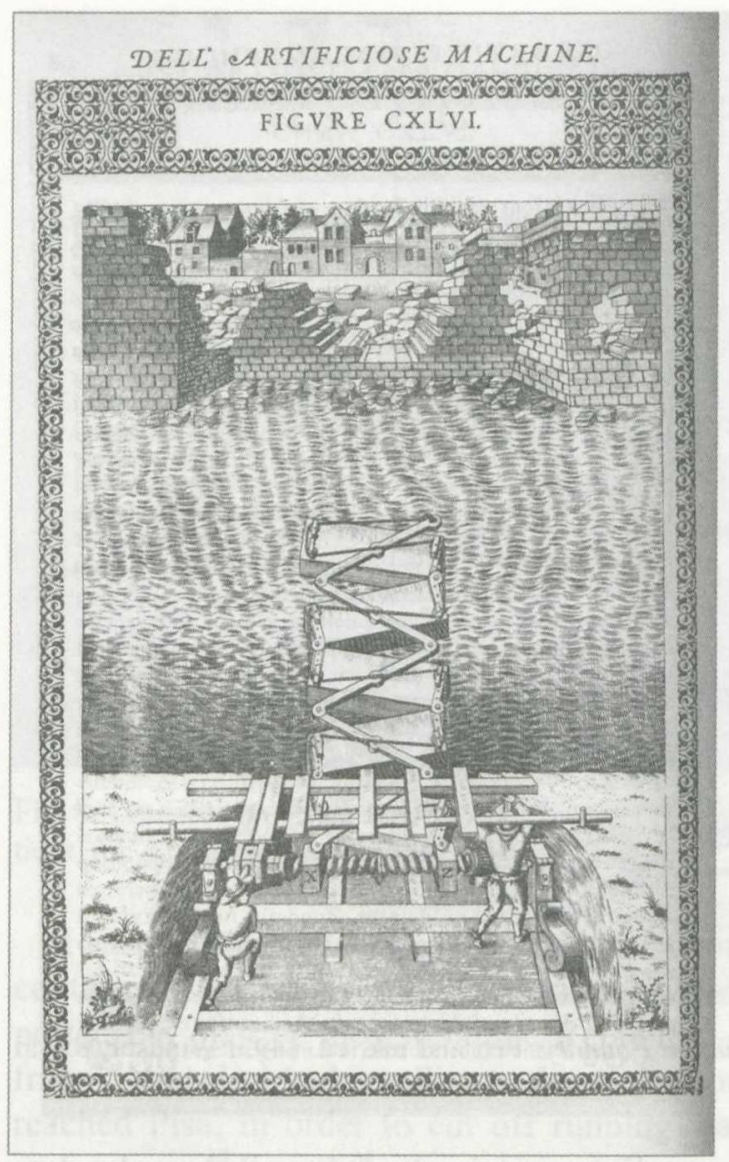

Fig. 6: Agostino Ramelli. Diverse et artificiose machine (Paris, 1588, fig. CXLVI).

organic apparatus, or rather transient incarnations of the forces of traction and thrust, with quite permeable contours.

The combination of perspective order and sketchiness, dynamic and organic forms, brings us to another point - the calculated non-finito of technical drawings, the rhetoric of the draft. Here too, Leonardo was a pioneer. Although there must have been many drawings like the representation of a big dredger digging a river-bed (fig. 8) - illustrations which by their perfection make the personal style of the draftsman almost disappear - the majority of sketches which contributed to the fame of Leonardo certainly displayed the evidence of their production. This can be deduced not only from the surviving technical drawings. It is evident because Leonardo's artistic production is also characterized by an aversion to completion and by a continuous preference for exploratory, open 


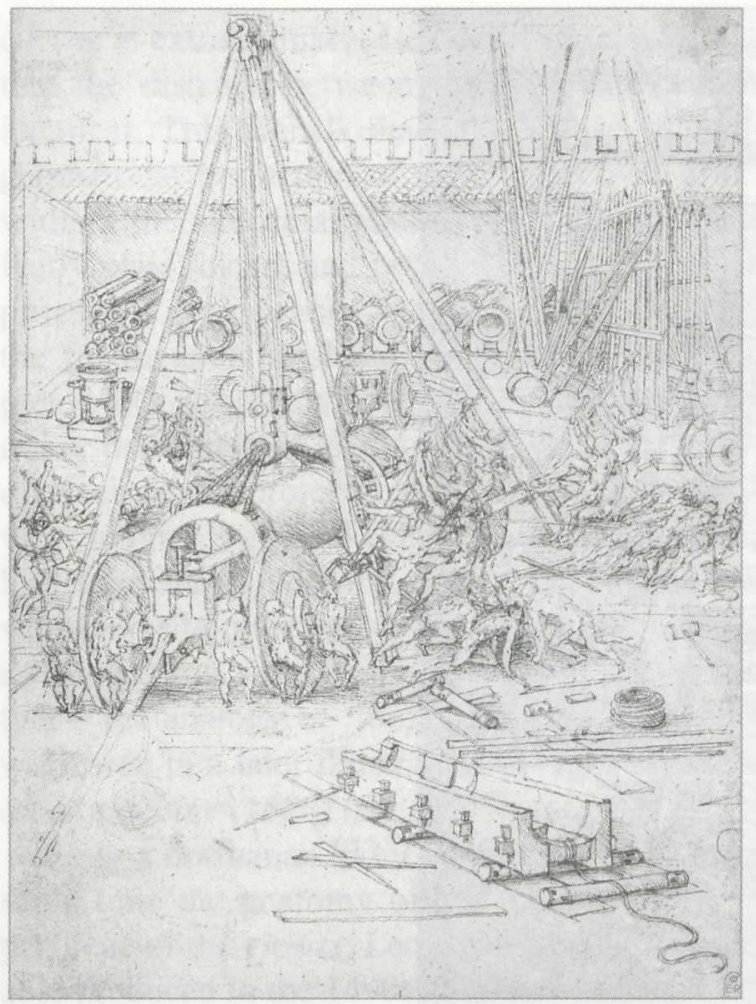

Fig. 7: Leonardo da Vinci. Cannon Foundry. Pen and ink, ca. 1495. Windsor, Royal Library, No. 12647.

techniques, with well-known disastrous results. ${ }^{36}$ It must have been an integral part of the technological rhetoric of Leonardo to reveal his process of sketching and drawing. The secretary of the Cardinal of Aragon, who visited Leonardo in 1517 in Clos Lucé, reported that Leonardo proudly presented the long series of his manuscripts - and we know how 'chaotic' most of these manuscripts appear. ${ }^{37}$

36 Cf. (for Leonardo's early work) Michael Wiemers. Bildform und Werkgenese. Studien zur zeichnerischen Bildvorbereitung in der italienischen Malerei zwischen 1450 und 1490. Munich and Berlin: Deutscher Kunstverlag, 1996. $265 \mathrm{ff}$.

37 After his visit to Leonardo in Cloux (10 October 1517), Antonio de' Beatis notes: "Ha anche composto de la natura de l'acqua, de diverse machine et altre cose [note the sequence!], secondo ha riferito lui, infinità di volumi et tutti in lingua volgare." Antonio de Beatis. Die Reise des Kardinals Luigi d'Aragona durch Deutschland, die Niederlande, Frankreich und Oberitalien 1517 bis 1518. Ed. Ludwig von Pastor. Freiburg: Herdersche Verlagshandlung, 1905. 143; cf. Carlo Pedretti. Leonardo da Vinci on Painting. A Lost Book (Libro A). Berkeley and Los Angeles: University of California Press, 1964. 109, and Pedretti. Literary Works. Vol. 2, 140. 


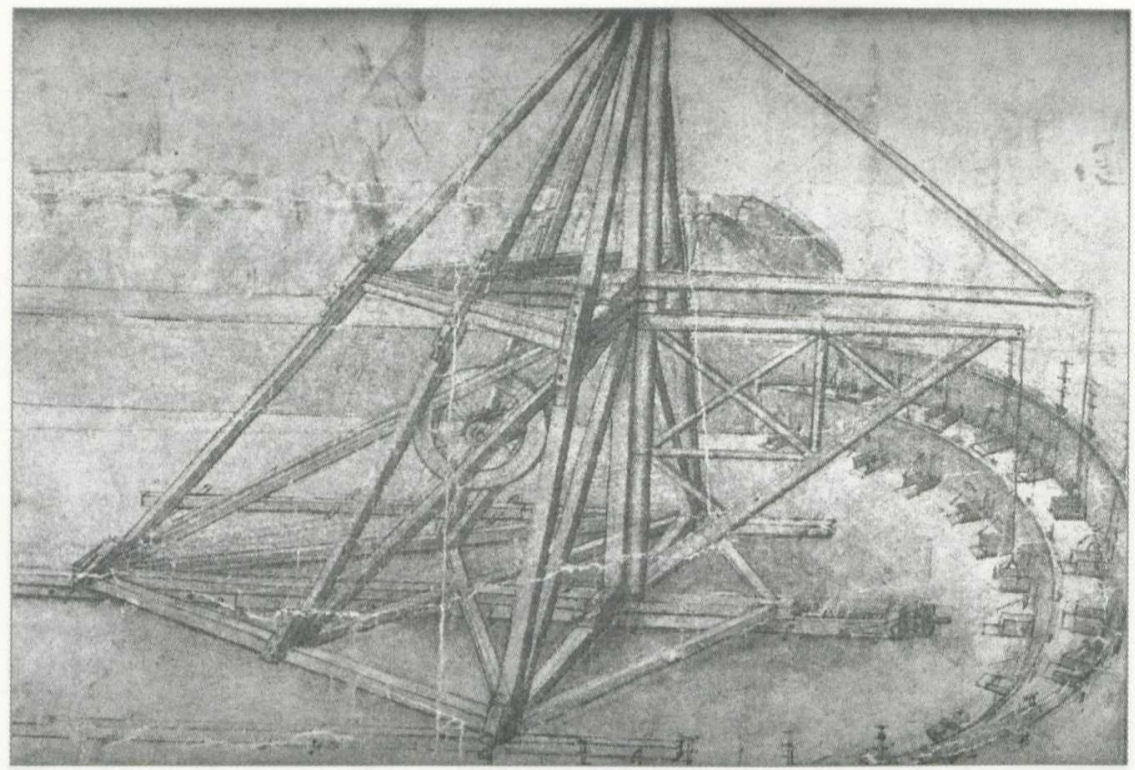

Fig. 8: Leonardo da Vinci. Project of a Dredger. Pen and ink, ca. 1500. Codex Atlanticus, fol. 4 recto. Milan, Biblioteca Ambrosiana.

I suspect that the 'ingenious' state of Leonardo's technical projects contributed enormously to his persuasive eros. In 1504, Leonardo supported the plan of the Florentine Republic - a favorite project of his friend, Niccolò Machiavelli - to divert the course of the Arno before it reached Pisa, in order to cut off running water and the sea from the arch-enemy. ${ }^{38}$ Soon after work began, the operations at the construction site, where over two thousand workers were employed at some time, had to be abandoned in face of the insurmountable difficulties of this giant enterprise. At the same time, Leonardo developed a project to render the Arno navigable from Florence to the sea. The entire Val di Chiana, to the south of Arezzo, was to be flooded, serving as a reservoir for the river, and the rapids near Empoli were to be bypassed by a broad diversion of the Arno to the north. Part of the project was a canalised tunnel at Serravalle (near Lucca), after which the river would return to its original bed. ${ }^{39}$ Leonardo's faith in the production of almost unlim-

38 On this project, cf. Nicolai Rubinstein. "Machiavelli and the Decoration of the Hall of the Great Council in the Palazzo Vecchio." Musagetes. Festschrift für Wolfram Prinz. Ed. Ronald G. Kecks. Berlin: Mann, 1991. 275-85.

39 Ladislao Reti. "Leonardo the Technologist. The Problem of the Prime Mover." Idem and Bern Dibner. Leonardo da Vinci, Technologist. Norwalk: Burndy Library, 1969. 90 . 


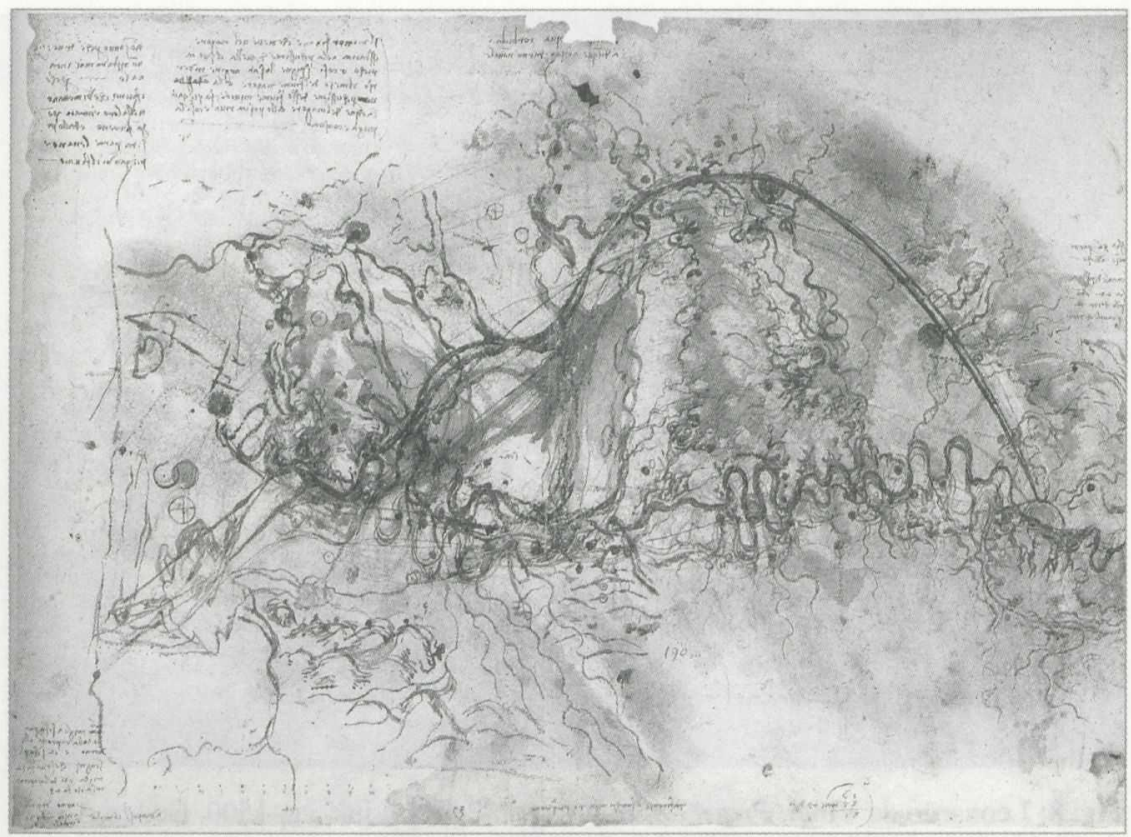

Fig. 9: Leonardo da Vinci. Map of the Arno. Various media, 1503/04. Windsor, Royal Library, No. 12279.

ited forces was, at that time, still intact, although the development of the flying machine sounded a note of caution. ${ }^{40}$ In 1495 , Leonardo contemplated a cannon that would somehow shoot the earth off its central position in the universe - a technological phantasmagoria, significantly connecting Archimedes, gunpowder, and Nicolaus Copernicus. ${ }^{41}$

A large map of 1503/4 (fig. 9), also in Windsor Castle, is a very elaborate product in different media (pen with brown ink, black chalk, bistre), showing the new course of the Arno in a bold, sweeping line. In its combination of geographical exactitude (note the tributaries of the Arno!) and "impure," alternative channel courses, drawn nevertheless with great decisiveness, the drawing is a telling example of the ideal

40 Cf. Frank Fehrenbach. "Hier stehe ich, aber mein Auge durcheilt die Räume. Die Vogelstudien und Flugversuche von Leonardo da Vinci." Frankfurter Allgemeine Zeitung (April 27, 2002): 47.

41 Leonardo da Vinci. Codex Madrid I, first flyleaf recto: "Se possibile fussi fare una bonbarda, che '1 mondo fussi sua ballotta, e che sicome una bonbarda gitta una balotta d'un braccio 3 miglia, che si pò misurare il tal corso 9000 braccia, cioè 9 mila ballotte. Noi possiamo adunque dire, che tal bonbarda gitterebbe il nostro mondo novemila volte la grandeza del diamitro d'esso mondo distante da ssè. [Sare]bono a settemila miglia per mondo, sarebono 63 migliara di miglia." 
mixture (and its ethical connotations) of know-how, accuracy, and courage - scientia, diligentia/cura, and potestas audendi - which must have hypnotized administrators. The combined trust in God and in the good outcome of high tech projects seem to mesmerize not only modern governments; as is well known, the plans for the new Florentine Cathedral, for instance, were revised in the second half of the $14^{\text {th }}$ century without clear ideas about how to close the giant space of the cupola. ${ }^{42}$ Leonardo's ingenious drawing of the Arno sheds some light on the significant moments of these planning procedures. We can imagine Leonardo drawing the new course of the river on the large sheet of paper, over the landscape, in a sweeping left-hand gesture, mimetically following the course of the water from right to left, with a wet brush, and perhaps right before the eyes of an admiring audience.

\section{III.}

Before 1500 , Leonardo as draftsman used mainly metal point (a medium not allowing corrections) and, to an even larger extent, pens of different size. As a common medium for sketching and writing, the pen underlines the priority of 'painting' over writing; even letters are, in this perspective, nothing but another form of drawing. ${ }^{43}$ After 1500 , Leonardo employs a wider range of graphic materials - red and black chalks, pastels, charcoals, and watercolors. ${ }^{44}$ These diverse media create different visual effects, and these effects are, in turn, related to the particular physical qualities of the objects. The early drawings of Leonardo already document a very accurate differentiation of media. Quite often the draftsman works with the dry stilus, creating colorless, 'ghostlike' lines imprinted in the paper. These lines are visible only with close attention and oblique illumination; they cannot be reproduced by any means. The reproductions we hold in our hands, in more and more weighty publications, show just the 'surface' of an œuvre that borders on the invisible. After drawing these 'ghost lines,' the subtle figurations of the silver point adumbrate the represented object. The later application of pen and ink defines contours and shadows - or lead to new deformations by means of dynamic pentimenti.

42 Cf. Margaret Haines. "Brunelleschi and Bureaucracy: The Tradition of Public Patronage at the Florentine Cathedral." I Tatti Studies 3 (1989): 89-125.

43 Cf. Leonardo. Libro di pittura. § 23.

44 Cf. Francis Ames-Lewis. La matita nera nella pratica di disegno di Leonardo da Vinci (= Lettura Vinciana, vol. 41). Florence: Giunti, 2002. 
After 1500, Leonardo's graphic media reflect the qualities of the objects represented. This is particularly evident, for example, in the large studies of facial expressions for the Battle of Anghiari, intended to decorate the republican sanctuary of Leonardo's city, the Sala del Maggior Consiglio in the Palazzo Vecchio. Two drawings in Budapest depict older, experienced warriors and a youthful soldier (fig. 10 \& 11). While the wrinkled soldiers, with their wrathful grimaces, were executed in the darker and more brittle black chalk, for the shouting young man Leonardo chose the harder, sharper and at the same time 'blood-colored' red chalk (Italian: sanguigna). ${ }^{45} \mathrm{~A}$ few years later, Leonardo worked on a series of topographical representations of the Alps (W 12414), employing red chalk again, this time on red paper, with some white highlights, in order to visualize the firm consistency of the mountains. The more or less contemporary series of fantastical mountain landscapes, showing wavering, overhanging, and exploding rocks, was executed, however, in soft charcoal. Adhering only loosely to the paper ground, the medium complements the fragility and transient nature of the subject. Material disconnection instead of firm joints features prominently in the so-called 'Deluge Series' (W 12376-12386, ca. 1515), for which Leonardo initially, experimented with pen and ink. When he realized the inadequacy of the medium he completed the other drawings in black chalk.

The mimesis, or - more adequately - metonymy of the media present the material qualities of the objects of representation. A similar metonymy can be observed in the development of Leonardo's technique of hatching. As a strongly conventionalized and regionally astonishingly constant workshop technique, hatching has never been a subject of systematic representational analysis. ${ }^{46}$ It was not a topic of literary debate; therefore historical hermeneutics is not provided with a terminological framework. This lack of interest is astonishing, since the graphic representation of three-dimensionality proves the inadequacy of the com-

45 Domenico Laurenza. "Corpus mobile. Ansätze einer Pathognomik bei Leonardo." Leonardo da Vinci. Natur im Übergang. Beiträge zu Kunst, Wissenschaft und Technik. Ed. Frank Fehrenbach. Munich: Fink, 2002. 257-301.

46 Cf. Bernhard Degenhart. "Zur Graphologie der Handzeichnung. Die Strichbildung als stetige Erscheinung innerhalb der italienischen Kunstkreise." Kunstgeschichtliches Jahrbuch der Bibliotheca Hertziana 1 (1937): 223-343. (I would like to thank Heiko Damm for bringing this article to my attention.) - In the recent, historically very broad and theoretically ambitious study of drawings by David Rosand, hatching is not discussed systematically (Drawing Acts. Studies in Graphic Expression and Representation. Cambridge: Cambridge University Press, 2002). Convincing remarks on the tactility of hatching types, ibid. 107 and 110f. (Leonardo); on temporality: 111 (Leonardo) and 206f. (Michelangelo). 


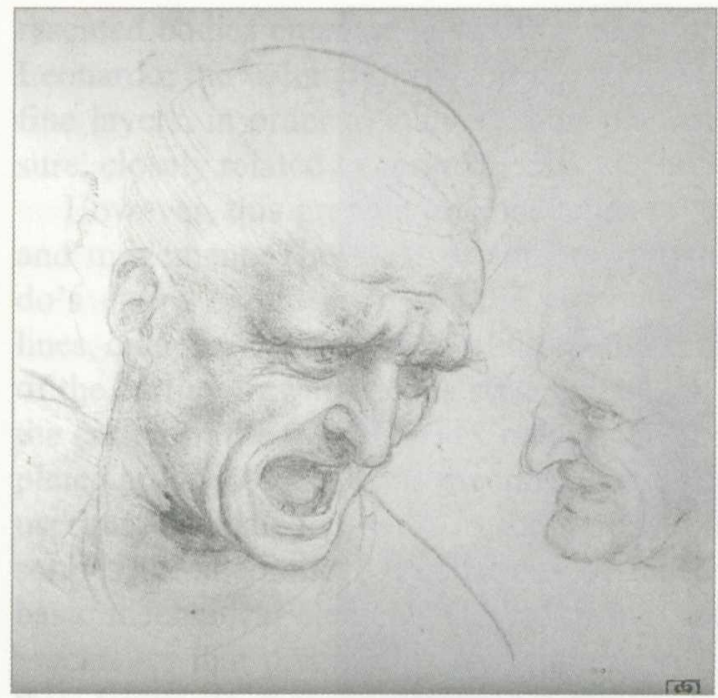

Fig. 10: Leonardo da Vinci. Study for the "Battle of Anghiari." Black chalk, ca. 1504. Budapest, Szépmüvészeti Múzeum, No. 1774.

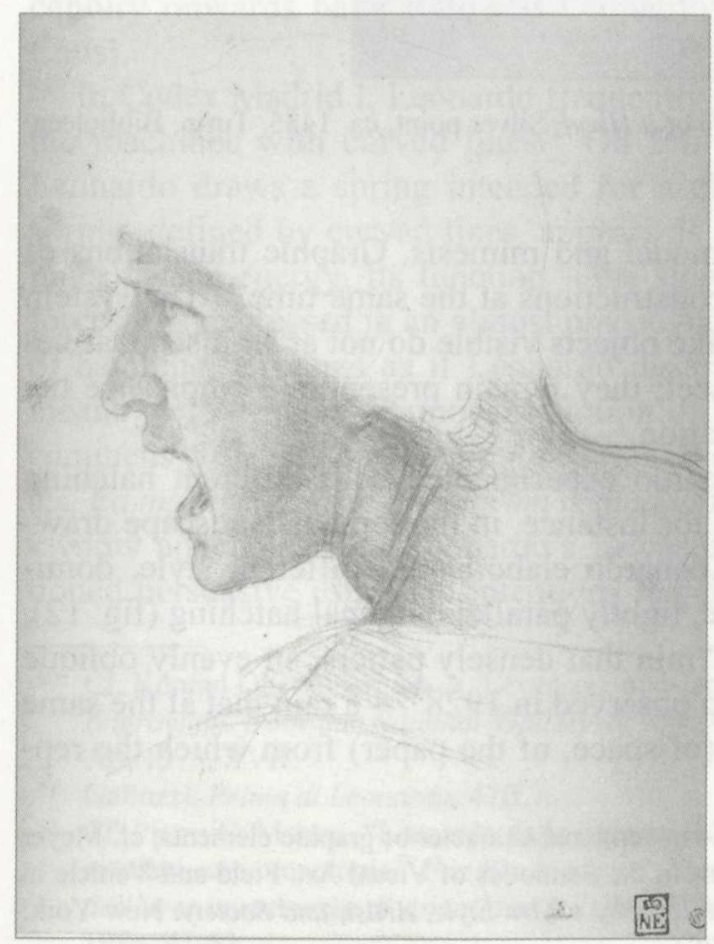

Fig. 11: Leonardo da Vinci. Study for the "Battle of Anghiari." Red chalk, ca. 1504. Budapest, Szépmüvészeti Múzeum, No. 1775. 


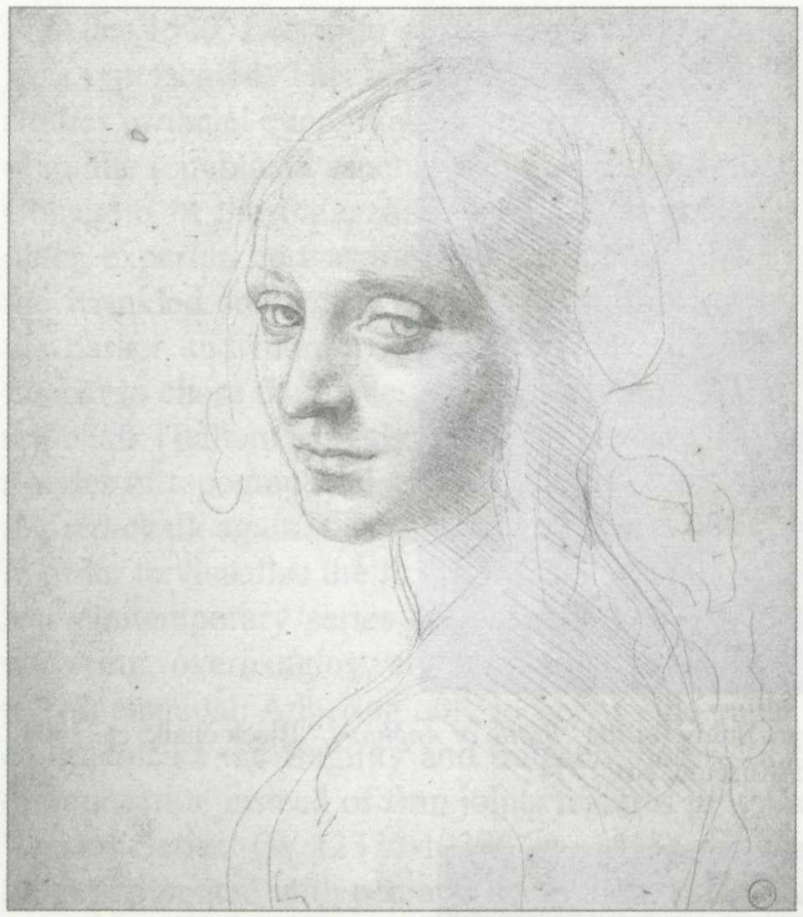

Fig. 12: Leonardo da Vinci. Study of a Head. Silver point, ca. 1485. Turin, Biblioteca Reale, No. 15572.

mon distinctions between model and mimesis. Graphic translations of objects are imitations and constructions at the same time. ${ }^{47}$ The system of lines and hatches that make objects visible do not at all disappear behind the illusion of the object; they remain present and emphasize the artificiality of the representation.

As a young artist, Leonardo experimented with different hatching techniques, as can be seen, for instance, in the famous landscape drawing of $1473 .{ }^{48}$ In Milan, Leonardo elaborated a different style, dominated by extremely accurate, tightly parallel diagonal hatching (fig. 12), giving the impression of a "rain that densely patters, an evenly oblique rain shower", as Anny Popp observed in $1928^{49}$ - a rain that at the same time visualizes a 'ground' (of space, of the paper) from which the rep-

47 On the non-mimetic and non-conventional character of graphic elements, cf. Meyer Schapiro. "On Some Problems in the Semiotics of Visual Art. Field and Vehicle in Image-Signs." Theory and Philosophy of Art. Style, Artist, and Society. New York: Braziller, 1994. 1-32 (esp. 27f.).

48 Florence, Uffizi, GDS inv. no. 8P.

49 Anny E. Popp. Leonardo da Vinci. Zeichnungen. Munich: Piper, 1928. 25. 
resented bodies emanate in subtle gradation. Applied by a virtuoso like Leonardo, the volume of objects seems to be defined as a relief, in very fine layers, in order to suggest their plasticity. The technique is, to be sure, closely related to contemporary engravings. ${ }^{50}$

However, this graphic practice tends to 'freeze' depictions of action and movement. The most prominent stylistic modification in Leonardo's entire œuvre concerns the elaboration of hatching with curved lines, complementing and substituting the straight, parallel diagonal lines of the earlier drawings. This style can be observed, for the first time, in the earlier of the two Madrid Codices, rediscovered only in 1966. Completed around 1495, this is the most elaborate of all of Leonardo's manuscripts, dedicated entirely to the axioms of mechanics. Leonardo describes the theoretical foundations of mechanical forces and presents basic mechanical elements (lever, spring, spindle, etc.), an alphabet of mechanics that precedes every application in concrete machines. With this, Leonardo moves, historically for the first time, from engineering to systematic research in mechanics, or from technique to technology. ${ }^{51}$ With significant delay, books on machines from the end of the sixteenth century onwards have followed Leonardo's model (e.g. Salomon de Caus).

In Codex Madrid I, Leonardo frequently hatches various elements of the machines with curved lines. ${ }^{52}$ On fol. 45 r (fig. 13), for instance, Leonardo draws a spring intended for a clockwork. The body of the spring, defined by curved lines, appears as a monumental form, full of inner plastic energy. Its function - the slow, circular release of stored forces - is expressed in an almost physiognomic manner by the method of hatching. It seems as if Leonardo discovered the adequate graphic means for Vitruvius's famous defintion of the machina: "Machina est continens e materia coniunctio, maximas ad onerum motus habens virtu-

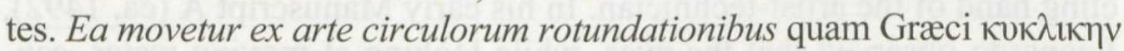

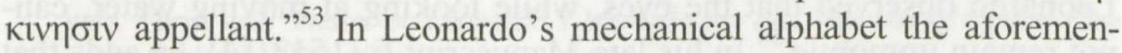
tioned persuasive esthetical intentions reappear: perspective, geometry,

50 Cf. Konrad Oberhuber, Jay A. Levenson, and Jacquelyn L. Sheehan. Early Italian Engravings from the National Gallery of Art. Washington: National Gallery of Art, 1973. XVff.

51 Galluzzi. Prima di Leonardo. $47 \mathrm{ff}$.

52 Cf. Pietro C. Marani. "Leonardo dalla scienza all'arte; un cambiamento di stile, gli antefatti, una cronologia." Fra Rinascimento, Manierismo e Realtà. Scritti di storia dell' arte in memoria di Anna Maria Brizio. $2^{\text {nd }}$ ed. Ed. idem. Florence: Barbèra, 1984. 41-52.

53 Vitruvius. On Architecture. 2 vols. Trans. F. Granger. Cambridge: Harvard University Press, 1962. Vol. 2, 274 [my emphasis]. 


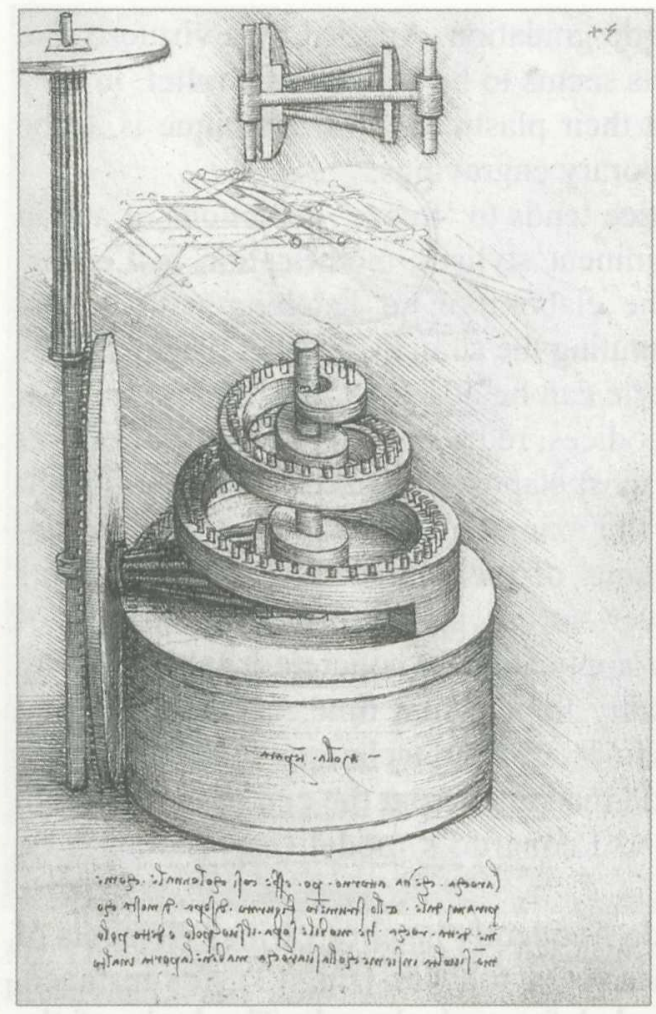

Fig. 13: Leonardo da Vinci. Spring. Pen and ink, ca. 1492. Codex Madrid I, fol. 45r. Madrid, Biblioteca Nacional.

and movement. Even the individual elements of the mechanical organism seem 'rhetorical.'

Consequently, the perceiving eye of the viewer merges with the modeling hand of the artist-technician. In his early Manuscript A (ca. 1492), Leonardo observed that the eyes, while looking at moving water, cannot remain immobile. ${ }^{54}$ In his late Manuscript E (1513/14), he adds that seeing is normally in motion, thus drawing a line through the visual field - to extrapolate, like a draftsman who moves a point in creating a line. ${ }^{55}$ This theoretical background is made manifest by means of curved

54 "Se tu riguardi il movimento dell'acqua, l'occhio tuo non si può fermare ma fa a similitudine delle cose vedute." Manuscript A, fol. $58 \mathrm{v}$.

55 Cf. Manuscript E, fol. 80v; also 34v, 35r (in the context of transformation geometry; cf. Matilde Macagno. Geometry in Motion in the Manuscripts of Leonardo da Vinci. Iowa City: University of Iowa Press, 1987). On the relationship of curved hatching and the mobile eye, cf. also Donald S. Strong. Leonardo on the Eye. An English Translation and Critical Commentary of MS. D in the Bibliothèque Natio- 
hatching. The eye itself weaves the objects of images, and its movement projects a modeling veil on moving things, merging with their graphic creation and expansive dynamics. ${ }^{56}$

Again, Leonardo's graphic strategy connects the privileged viewer with the production of images. His technical drawings, too, connect the producing instrument - the pen of the draftsman - to the eye of the viewer. To put it somewhat pointedly: The graphic suggestion works, because it is the addressee himself who produces it. Every spectator becomes a 'drawing sovereign.'

\section{IV.}

The rhetoric of drawing at the origins of instruments and technical practices - the later history of this constellation in the sixteenth and seventeenth centuries would be a separate and urgent research project, necessarily including not only the printed, but also the manuscript sources of the history of technology in a comprehensive way. ${ }^{57}$ At this point, only a few concluding observations could be made. The printed engineering treatises of the sixteenth and seventeenth centuries address mainly the socially high-ranking dilettante and belong therefore to the field of lusus. The rare and highly appreciated dedicated machine book manuscripts of the sixteenth century present their (partly non-functional) mechanical devices in perfect integrity, frequently relying in their perspective constructions on Francesco di Giorgio. In 1671, in a letter to the Duke of Hanover, the later King George I of England, Gottfried Wilhelm Leibniz rejects these 'dead' - immobile - machines, created for a distanced, to extrapolate: esthetic contemplation. ${ }^{58}$ At this time, Leonardo's singular 'physiognomic' skills in presenting machines and

nale, Paris, with Studies on Leonardo's Methodology and Theories of Optics. New York: Garland, 1979. 408f.

56 But compare the too narrow view, following Gotthold Ephraim Lessing, of Daniela Lamberini: "It is impossible to represent movement on a two-dimensional surface (and dynamic motion is the intrinsic characteristic of the machina, as opposed to the fabrica, or building, the static machine par excellence)." Daniela Lamberini. "Machines in Perspective. Technical Drawings in Unpublished Treatises and Notebooks of the Italian Renaissance." The Treatise on Perspective. Published and Unpublished (= Studies in the History of Art 59 - Symposium Papers XXXVI). Ed. Lyle Massey. New Haven and London: Yale University Press, 2003. 213-33 [214].

57 Cf. the survey by Hélène Vérin. La gloire des ingénieurs. L'intelligence technique du XVIe au XVIIIe siècle. Paris: Albin Michel, 1993.

58 Cf. Lamberini. "Machines in Perspective." 213 (following Manlio Brusatin. Storia delle linee. Turin: Einaudi, 1993. 52). 
their elements in a dynamic, rhetorical manner were already substituted by graphic conventions and by the increasingly important three-dimensional model making. ${ }^{59}$ Historically, the hand-'writing' of the drawing technician survived only in the stenographic milieu of the workshop manuscripts and in architectural drawing. ${ }^{60}$ At the end of the eighteenth century, the military engineer Gaspard Monge and his collaborator Jean Nicolas Pierre Hachette 'purged' the genre of technical drawings of its last rhetorical elements (among them the perspectival relationship between viewer and functional object). What remains are the elements of machines, ordered in table form, and visualized as section and diagram. ${ }^{61}$

\section{WORKS CITED}

Alberti, Leon Battista. On Painting. New York: Penguin, 1991.

Ames-Lewis, Francis. La matita nera nella pratica di disegno di Leonardo da Vinci (= Lettura Vinciana, vol. 41). Florence: Giunti, 2002.

Aristotle. De partibus animalium/Parts of animals. Trans. A.L. Peck. Cambridge: Cambridge University Press, 1983.

Bacher, Jutta. "Das Theatrum machinarum. Eine Schaubühne zwischen Nutzen und Vergnügen." Erkenntnis - Erfindung - Konstruktion. Studien zur Bildgeschichte von Naturwissenschaften und Technik vom 16. bis zum 19. Jahrhundert. Ed. Hans Holländer. Berlin: Mann, 2000. 509-18.

Bacher, Jutta. '“Ingenium vires superat.' Die Emanzipation der Mechanik und ihr Verhältnis zu Ars, Scientia und Philosophia." Erkenntnis - Erfindung - Konstruktion. Studien zur Bildgeschichte von Naturwissenschaften und Technik vom 16. bis zum 19. Jahrhundert. Ed. Hans Holländer. Berlin: Mann, 2000. 519-55.

Barkan, Leonard. Unearthing the Past. Archeology and Aesthetics in the Making of Renaissance Culture. New Haven and London: Yale University Press, 1999.

Bredekamp, Horst. "Der Mensch als 'zweiter Gott.' Motive der Wiederkehr eines kunsttheoretischen Topos im Zeitalter der Bildsimulation." Interface 1. Elektronische Medien und künstlerische Kreativität. Ed. Klaus Peter Dencker. Hamburg: Verlag Hans-Bredow-Institut für Rundfunk und Fernsehen, 1992. 134-47.

Bredekamp, Horst. Antikensehnsucht und Maschinenglauben. Die Geschichte der Kunstkammer und die Zukunft der Kunstgeschichte. Berlin: Wagenbach, 1993.

Britton, Pierce Dominic. "Lionizing Leonardo. A Physiognomic Conceit in Vasari's 'Vite."' Source 22.4 (2003): 10-15.

Brusatin, Manlio. Storia delle linee. Turin: Einaudi, 1993.

59 On the relationship of drawing and model, cf. also Massimo Scolari. "Elementi per una storia dell'assonometria." Casabella 550 (March 1984): 42-49.

60 On architectural drawings, ef. Werner Oechslin. "Von Piranesi zu Libeskind. Erklären mit Zeichnung." Daidalos 1 (1981): 15-19.

61 Cf. Sandrina Khaled. "Pikturale Graphismen der Technik, 1569-1870." Bilder in Prozessen (= Bildwelten des Wissens. Kunsthistorisches Jahrbuch für Bildkritik, vol. 1.1). Ed. Horst Bredekamp and Gabriele Werner. Berlin: Akademie Verlag, 2003. 64-78. 
Butters, Suzanne B. The Triumph of Vulcan. Sculptor's Tools, Porphyry, and the Prince in Ducal Florence. 2 vols. Florence: Olschki, 1996.

Castiglione, Baldassare. Il libro del cortegiano. Ed. Walter Barberis. Turin: Einaudi, 1998.

Clark, Kenneth. The Drawings of Leonardo da Vinci in the Collection of H. M. The Queen at Windsor Castle. 3 vols. London: Phaidon, 1968.

Costamagna, Philippe. Pontormo. Milan: Electa, 1994.

Degenhart, Bernhard. "Zur Graphologie der Handzeichnung. Die Strichbildung als stetige Erscheinung innerhalb der italienischen Kunstkreise." Kunstgeschichtliches Jahrbuch der Bibliotheca Hertziana 1 (1937): 223-343.

Didi-Huberman, Georges. Confronting Images. Questioning the Ends of a Certain History of Art. Pennsylvania: Pennsylvania State University Press, 2005.

Farago, Claire J. Leonardo da Vinci's 'Paragone.' A Critical Interpretation with a New Edition of the Text of the 'Codex Urbinas. 'Leiden: Brill, 1992.

Fehrenbach, Frank. Licht und Wasser. Zur Dynamik naturphilosophischer Leitbilder im Werk Leonardo da Vincis. Tübingen: Wasmuth, 1997.

Fehrenbach, Frank. "Hier stehe ich, aber mein Auge durcheilt die Räume. Die Vogelstudien und Flugversuche von Leonardo da Vinci." Frankfurter Allgemeine Zeitung (April 27, 2002): 47.

Fehrenbach, Frank. "Komposition." Metzler Lexikon Kunstwissenschaft. Ideen, Methoden, Begriffe. Ed. Ulrich Pfisterer. Stuttgart and Weimar: Metzler, 2003. 178-83.

Furttenbach, Joseph. Mechanische Reißladen ... Augsburg, 1644.

Galluzzi, Paolo, ed. Prima di Leonardo. Cultura delle macchine a Siena nel Rinascimento. Milan: Electa, 1991.

Galluzzi, Paolo. Gli ingegneri del Rinascimento da Brunelleschi a Leonardo da Vinci. Florence: Giunti, 2001.

Haines, Margaret. "Brunelleschi and Bureaucracy: The Tradition of Public Patronage at the Florentine Cathedral." I Tatti Studies 3 (1989): 89-125.

Hambly, Maja. Drawing Instruments. 1580-1980. London: Wilson, 1988.

Holländer, Hans. "Spielformen der Mathesis universalis." Erkenntnis - Erfindung - Konstruktion. Studien zur Bildgeschichte von Naturwissenschaften und Technik vom 16. bis zum 19. Jahrhundert. Ed. idem. Berlin: Mann, 2000. 325-345.

Kemp, Martin. The Science of Art. Optical Themes in Western Art from Brunelleschi to Seurat. New Haven and London: Yale University Press, 1990.

Kemp, Wolfgang. : . e einen wahrhaft bildenden Zeichenunterricht überall einzuführen.' Zeichnen und Zeichenunterricht der Laien 1500-1870. Ein Handbuch. Frankfurt a.M.: Syndikat, 1979.

Khaled, Sandrina. "Pikturale Graphismen der Technik, 1569-1870." Bilder in Prozessen (= Bildwelten des Wissens. Kunsthistorisches Jahrbuch für Bildkritik, vol. 1.1). Ed. Horst Bredekamp and Gabriele Werner. Berlin: Akademie Verlag, 2003. 64-78.

Körner, Hans. Auf der Suche nach der 'wahren Einheit.' Ganzheitsvorstellungen in der französischen Malerei und Kunstliteratur vom mittleren 17. bis zum mittleren 19. Jahrhundert. Munich: Fink, 1988.

Koerner, Joseph Leo. The Moment of Self-Portraiture in German Renaissance Art. Chicago: University of Chicago Press, 1993.

Krohn, Wolfgang. "Technik, Kunst und Wissenschaft. Die Idee einer konstruktiven Naturwissenschaft des Schönen bei Leon Battista Alberti." Leonardo da Vinci. Natur im Übergang. Beiträge zu Kunst, Wissenschaft und Technik. Ed. Frank Fehrenbach. Munich: Fink, 2002. 37-56.

Lamberini, Daniela. "Machines in Perspective. Technical Drawings in Unpublished 
Treatises and Notebooks of the Italian Renaissance." The Treatise on Perspective. Published and Unpublished (= Studies in the History of Art 59 - Symposium Papers XXXVI). Ed. Lyle Massey. New Haven and London: Yale University Press, 2003. 213-33.

Laurenza, Domenico. "Leonardo. Le macchine volanti." Le macchine del Rinascimento. Ed. Giovanni Morello. Rome: Retablo, 2000. 145-87.

Laurenza, Domenico. "Corpus mobile. Ansätze einer Pathognomik bei Leonardo." Leonardo da Vinci. Natur im Übergang. Beiträge zu Kunst, Wissenschaft und Technik. Ed. Frank Fehrenbach. Munich: Fink, 2002. 257-301.

Laurenza, Domenico. "Leonardo nella Roma di Leone X (c. 1513-16)." XLIII Lettura Vinciana. Florence: Giunti, 2004.

Laurenza, Domenico. Le macchine di Leonardo. Florence: Giunti, 2005.

Leonardo da Vinci. Il Codice Atlantico di Leonardo da Vinci nella Biblioteca Ambrosiana di Milano. Ed. Accademia dei Lincei. Transcribed by Augusto Marinoni. 24 vols. Florence: Barbèra, 1973-1980.

Leonardo da Vinci. Codices Madrid. Ed. Ladislao Reti and Augusto Marinoni. 5 vols. Frankfurt a.M.: Fischer, 1974.

Leonardo da Vinci. Libro di Pittura. Ed. Carlo Pedretti. Florence: Giunti, 1995.

Leonardo da Vinci. Il codice Arundel 263 nella British Library. Ed. Carlo Pedretti. Transcribed with commentary by Carlo Vecce. Florence: Giunti, 1998.

Macagno, Matilde. Geometry in Motion in the Manuscripts of Leonardo da Vinci. Iowa City: University of Iowa Press, 1987.

Marani, Pietro C. "Leonardo dalla scienza all'arte; un cambiamento di stile, gli antefatti, una cronologia." Fra Rinascimento, Manierismo e Realtà. Scritti di storia dell'arte in memoria di Anna Maria Brizio. $2^{\text {nd }}$ ed. Ed. idem. Florence: Barbèra, 1984. 41-52.

Maschat, Herbert. Leonardo da Vinci und die Technik der Renaissance. Munich: Profil, 1989.

Maurice, Klaus. Der drechselnde Souverän. Materialien zu einer fürstlichen Maschinenkunst. Zurich: Ineichen, 1985.

Oberhuber, Konrad, Jay A. Levenson, and Jacquelyn L. Sheehan. Early Italian Engravings from the National Gallery of Art. Washington: National Gallery of Art, 1973.

Oechslin, Werner. "Von Piranesi zu Libeskind. Erklären mit Zeichnung." Daidalos 1 (1981): 15-19.

Ovitt, George. The Restoration of Perfection. Labor and Technology in Medieval Culture. New Brunswick and London: Rutgers University Press, 1987.

Paniagua, Cecilio. "Notes on a Drawing by Leonardo da Vinci." International Review of Psychoanalysis 13 (1986): 445-52.

Pastor, Ludwig von, ed. Antonio de Beatis. Die Reise des Kardinals Luigi d'Aragona durch Deutschland, die Niederlande, Frankreich und Oberitalien 1517 bis 1518. Freiburg: Herdersche Verlagshandlung, 1905.

Pedretti, Carlo. Leonardo da Vinci on Painting. A Lost Book (Libro A). Berkeley and Los Angeles: University of California Press, 1964.

Pedretti, Carlo. The Literary Works of Leonardo da Vinci. Commentary. 2 vols. London: Phaidon, 1977.

Pfisterer, Ulrich, ed. Die Kunstliteratur der italienischen Renaissance. Eine Geschichte in Quellen. Stuttgart: Reclam, 2002.

Pliny the Elder, Gaius. Historia naturalis/Naturkunde. Latin/German. Ed. and trans. Roderich König. Munich and Darmstadt: Artemis \& Winkler, 1973ff.

Pliny the Elder, Gaius. Natural History. Trans. H. Rackham. Cambridge: Harvard University Press, 1979. 
Popp, Anny E. Leonardo da Vinci. Zeichnungen. Munich: Piper, 1928.

Puttfarken, Thomas. The Discovery of Pictorial Composition. Theories of Visual Order in Painting 1400-1800. New Haven and London: Yale University Press, 2000.

Reti, Ladislao. "Leonardo the Technologist. The Problem of the Prime Mover." Idem and Bern Dibner. Leonardo da Vinci, Technologist. Norwalk: Burndy Library, 1969.

Rosand, David. Drawing Acts. Studies in Graphic Expression and Representation. Cambridge: Cambridge University Press, 2002.

Rubinstein, Nicolai. "Machiavelli and the Decoration of the Hall of the Great Council in the Palazzo Vecchio." Musagetes. Festschrift für Wolfram Prinz. Ed. Ronald G. Kecks. Berlin: Mann, 1991. 275-85.

Schapiro, Meyer. "On Some Problems in the Semiotics of Visual Art. Field and Vehicle in Image-Signs." Theory and Philosophy of Art. Style, Artist, and Society. New York: Braziller, 1994. 1-32.

Scolari, Massimo. "Elementi per una storia dell'assonometria." Casabella 550 (March 1984): 42-49.

Strong, Donald S. Leonardo on the Eye. An English Translation and Critical Commentary of MS. D in the Bibliothèque Nationale, Paris, with Studies on Leonardo's Methodology and Theories of Optics. New York: Garland, 1979.

Summers, David. The Judgment of Sense. Renaissance Naturalism and the Rise of Aesthetics. $2^{\text {nd }}$ ed. Cambridge: Cambridge University Press, 1990.

Vasari, Giorgio. Le vite . . 6 vols. Ed. Rosanna Bettarini and Paola Barocchi. Florence: Sansoni, 1966-1987.

Veldman, Ilja M. and Ger Luijten. Maarten van Heemskerck. (= The New Hollstein. Dutch \& Flemish Etchings, Engravings, and Woodcuts 1450-1700). 2 vols. Amsterdam: Sound \& Vision Interactive, 1994.

Vérin, Hélène. La gloire des ingénieurs. L'intelligence technique du XVIe au XVIIIe siècle. Paris: Albin Michel, 1993.

Vitruvius. On Architecture. 2 vols. Trans. F. Granger. Cambridge: Harvard University Press, 1962.

Wiemers, Michael. Bildform und Werkgenese. Studien zur zeichnerischen Bildvorbereitung in der italienischen Malerei zwischen 1450 und 1490. Munich and Berlin: Deutscher Kunstverlag, 1996.

Williams, Robert. Art, Theory, and Culture in Sixteenth-Century Italy. From Techne to Metatechne. Cambridge: Cambridge University Press, 1997.

Woods-Marsden, Joanna. Renaissance Self-Portraiture. The Visual Construction of Identity and the Social Status of the Artist. New Haven and London: Yale University Press, 1998. 